\title{
TALL FESCUE \\ (Lolium arundinaceum (Schreb.) S.J. \\ Darbyshire) \\ CULTIVAR PERFORMANCE IN THE \\ CENTRAL CALIFORNIA COASTAL \\ REGION
}

\author{
A Thesis \\ Presented to the Faculty of \\ California Polytechnic State University \\ San Luis Obispo \\ In Partial Fulfillment \\ of the Requirements for the Degree of \\ Master of Science in Agriculture
}

By

Seril Shimizu

January 2010 
(C)2010

Seril T. Shimizu

ALL RIGHTS RESERVED 


\section{COMMITTEE MEMBERSHIP}

TITLE: Tall fescue (Lolium arundinaceum (Schreb.) S.J. Darbyshire) cultivar performance in the central California coastal region

AUTHOR: Seril Shimizu

DATE SUBMITTED: January 2010

COMMITTEE CHAIR: Dr. Terry Vassey

COMMITTEE MEMBER: Dr. David Headrick

COMMITTEE MEMBER: Dr. Ben Burgoa 


\begin{abstract}
TALL FESCUE (Lolium arundinaceum (Schreb.) S.J. Darbyshire) CULTIVAR PERFORMANCE IN THE CENTRAL CALIFORNIA COASTAL REGION
\end{abstract}

Seril Shimizu

January 2010

Tall fescue (Lolium arundinaceum (Schreb.) S.J. Darbyshire) has long been known as a turfgrass that utilizes lower levels of inputs than most other cool season turfgrasses (Turgeon, 2005). In recent years, turf breeders have been selecting for cultivars of tall fescue that have finer leaf textures. As the use of tall fescue expands, consumers want to now what cultivar to use and how to manage it. This study looked at 18 tall fescue cultivars grown at two mowing heights of five and 10 centimeters and evaluated plant quality based on stand density, leaf texture, and genetic plant color. In the first year of the study, although there were some differences, there were no continual patterns that proved one cultivar to be better or worst than the others. Lower mowing heights generally had higher stand density ratings and fertilization affected genetic plant color, not mowing height. There was no difference in leaf texture between mowing heights. 


\section{TABLE OF CONTENTS}

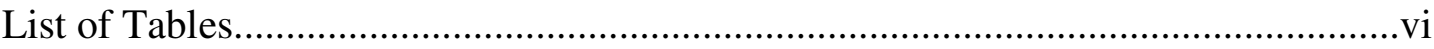

List of Figures.....................................................................................................

Chapter 1: Introduction and Literature Review...........................................

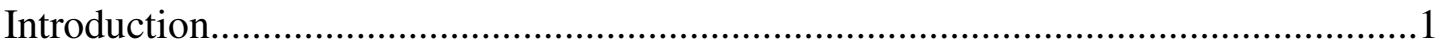

Background Information and Problem Statement.................................................

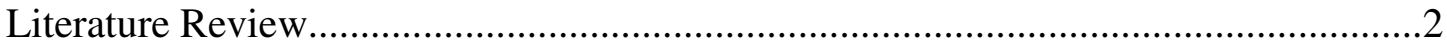

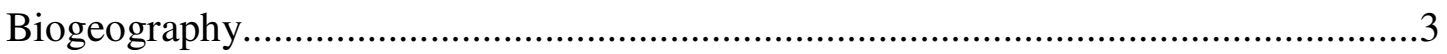

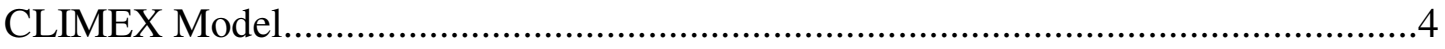

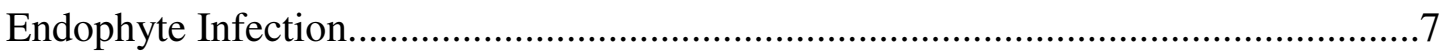

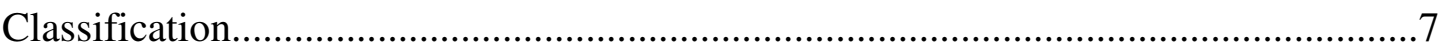

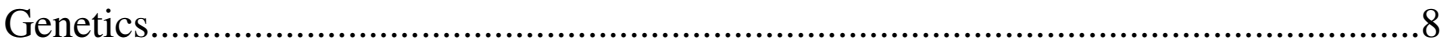

General Characteristics.............................................................................

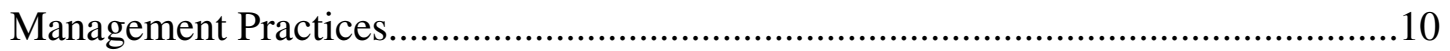

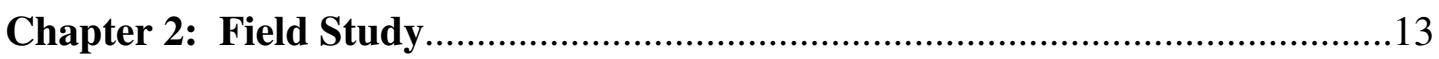

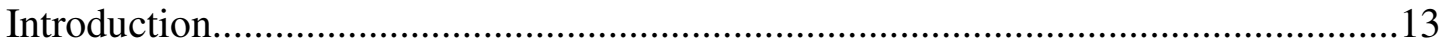

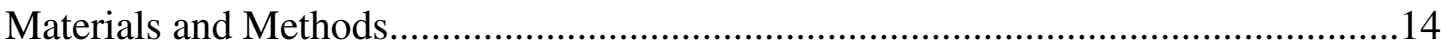

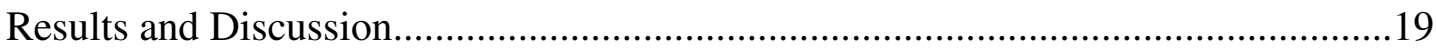

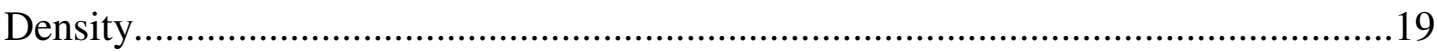

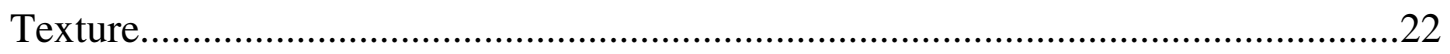

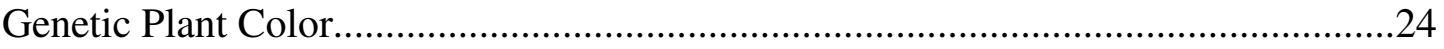

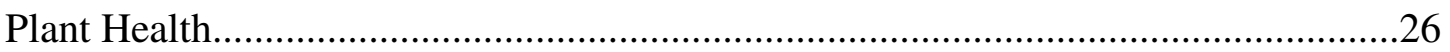

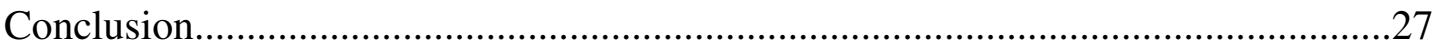




\section{LIST OF TABLES}

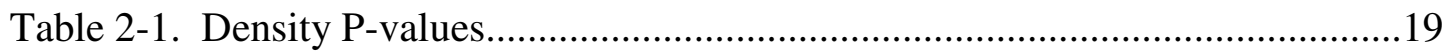

Table 2-2. Density ratings for May 2008 at given mow height...............................20

Table 2-3. Density ratings for July 2008 at given mow height..............................20

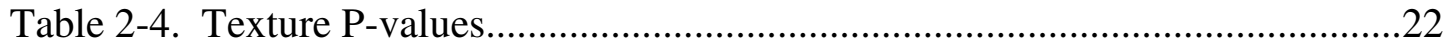

Table 2-5. Texture ratings for February 2008 at given mow height.........................22

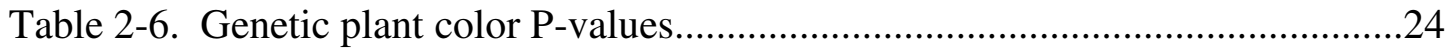

Table 2-7. Genetic plant color ratings for May 2008 at given mow height................25

Table 2-8. Genetic plant color ratings for July 2008 at given mowing height..........25 


\section{LIST OF FIGURES}

Figure 1-1. Tall fescue and perennial ryegrass unirrigated CLIMEX model of

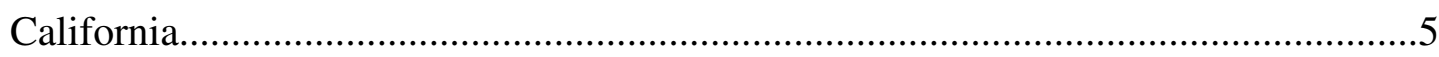

Figure 1-2. Tall fescue and perennial ryegrass irrigated CLIMEX model of

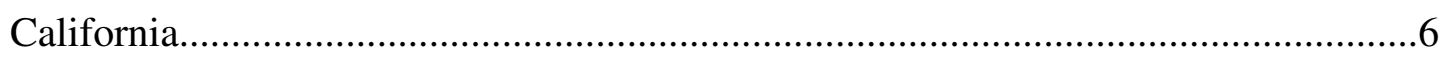

Figure 2-1. Tall fescue cultivars and sponsors used in experiment.........................15

Figure 2-2. Plot layout with solid lines indicating cultivar and dotted lines

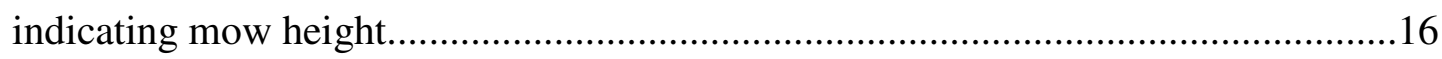

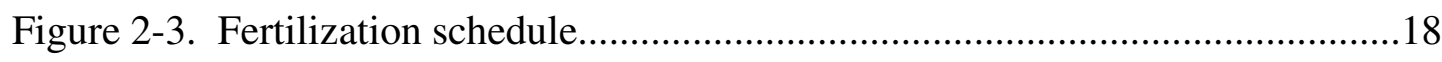

Figure 2-4. Mean densities by mow height over time.......................................21

Figure 2-5. Mean leaf texture by mow height over time......................................23

Figure 2-6. Mean genetic plant color by mow height over time.............................26 


\section{Chapter 1: Introduction and Literature Review}

\section{$\underline{\text { Introduction }}$}

\section{Background information and problem statement}

As resources become limited to today's society, we will need to make changes that comply with these and many more restrictions. The global demand for fresh water doubles every 20 years and this increase in need creates increasing competition for this resource (Duncan et al., 2000). Today, the most limiting factor in agriculture is irrigation water and managers will need to look at better, more effective ways to conserve this valuable resource.

There has been a drastic growth in popularity for sustainable turfgrass management practices in the past five years. This trend has led to many new and innovative techniques that have become commonplace.

Most recently, the golf course industry has come under fire as a high water consumer. Because of this perception, millions of dollars have been spent making irrigation systems more efficient. This has led to new water delivery systems with high irrigation efficiency ratings, most near 90\% (Snow, 2001).

Other things such as organic fertilizer use and the availability of reduced-risk pesticides have also become very important. Along with these new technologies, there has been renewed public pressure for turfgrass managers to become environmental stewards.

Golf course superintendents have become leaders in this movement through organizations such as Audubon International's Cooperative Sanctuary Program and the Golf Course Superintendents Association of America's (GCSAA) Environmental 
Institute. Programs such as these create strict environmental protection guidelines for golf courses to follow. Upon completion of programs like these, a certificate of accomplishment is awarded to the golf course facility.

Lastly, as irrigation technology reaches a performance efficiency threshold, golf course managers will have to make the move toward another new technology; more drought tolerant grass species. In addition, improved management practices that minimize the negative effects on the environment will have to become the norm.

Ultimately our goal for this project was to identify species grown at a given mowing height that may help minimize the adverse environmental effects poor management practices have on our environment. We hoped to evaluate the performance of tall fescue (Lolium arundinaceum) in the central California coast to identify cultivars well suited to this region. We recognize that tall fescue is often neglected for golf course use because of its perceived coarse texture, as many find this an unacceptable characteristic. Recently, new tall fescue cultivars have been introduced that have better leaf texture and are more similar to perennial ryegrass (Lolium perenne), a widely used turfgrass species in central California.

\section{LITERATURE REVIEW}

Tall fescue (Lolium arundinaceum (Schreb.) S.J. Darbyshire) is a vigorous turfgrass species that can often withstand periods of summer drought and higher temperatures. Tall fescue also requires fewer inputs, such as fertilizers and fungicides and withstands brief periods of drought without significant stand loss (Turgeon, 2005). When compared to the summer performance of Perennial ryegrass (Lolium 
perenne L.), tall fescue is better suited to hot, dry periods as well as poor soils. Unfortunately, tall fescue has a coarser leaf texture making it less suitable for highend turf use, especially on golf courses (Beard, 2002). For most high-end uses, clients expect a high quality turfgrass with a fine textured surface for improved aesthetics and playability. Plant breeders recognize this and efforts have been directed to improve and develop new tall fescue cultivars that have a finer leaf texture and improved color and playability (Ray, et al., 2007).

Perennial ryegrass is widely used throughout California on many golf courses, both as a fairway and rough grass. One desirable feature of perennial ryegrass is its very fine leaf texture, providing a very dense, high quality turfgrass stand especially at lower heights of cut. However, although an excellent turf, it requires very high amounts of water and up to 2.72 kilograms of nitrogen per 92.9 square meters per year especially where traffic is a problem (Beard, 2002).

\section{Biogeography}

Tall fescue's center of origin is Southern Europe, occurring from the Baltic coast, throughout the Caucasus, into western Siberia, and extending into China (Kasperbauer, 1990). Within this area, it is found growing in damp pastures and wet areas that were mainly used as forage for domesticated animals (Buckner \& Bush, 1979). Since its discovery, it has been introduced onto every continent except Antarctica.

Tall fescue was introduced to North America in the early to mid 1800's, most likely as a seed contaminant in meadow fescue (Festuca elatior) seed that was being 
used to establish forage pastures (Hoveland, undated). During this time, meadow fescue was the preferred choice as a forage grass in North America.

In 1931, a tall fescue ecotype from W.M. Suiter Farm in Menifee County, Kentucky was brought to the attention of Dr. E.N. Fergus at the University of Kentucky. This ecotype had superior traits for grazing tolerance and winter/cold color. It was eventually released as the cultivar 'Kentucky 31' in 1943 (Lacefield \& Evans, 1984). Since then, tall fescue has become the predominant cool-season grass species in North America, grown on an estimated 35 million acres, most of which a result of introduced seedings (Kasperbauer, 1990).

In North America, tall fescue is widely distributed throughout the continent. It performs best in well drained clay soils in climatic zones between subtropical and temperate (Duble, undated). The adaptation and distribution of tall fescue is influenced by climatic (rainfall and temperature), edaphic (soil water and texture), and geographic (latitude and elevation) factors (Kasperbauer, 1990).

\section{CLIMEX ${ }^{\mathrm{TM}}$ Model}

Using CLIMEX ${ }^{\mathrm{TM}}$ for Windows Version 1.1, predicted distribution for both tall fescue and perennial ryegrass were plotted on a map of California. CLIMEX ${ }^{\mathrm{TM}}$ uses environmental parameters to predict where species can be located. In this program, histories from numerous weather stations throughout California are stored. Using the literature, environmental parameters for both tall fescue and perennial ryegrass were input into the program. CLIMEX ${ }^{\mathrm{TM}}$ then marked the areas in California that had the highest probability of each grass showing up there. As a 
reference, both species were plotted to their natural range to ensure that the environmental parameters for each were correct.

When looking at the unirrigated model (Figure 1-1), we found those areas which are better suited for both species without irrigation. If the plant is better suited to the area without irrigation, then less irrigation water will be needed. This in turn can help us choose turfgrasses that are better suited to an area which in turn will mean less resource inputs. In this model, we found that tall fescue is better suited for California than perennial ryegrass.

Figure 1-1. Tall fescue and perennial ryegrass unirrigated CLIMEX ${ }^{\mathrm{TM}}$ model of California

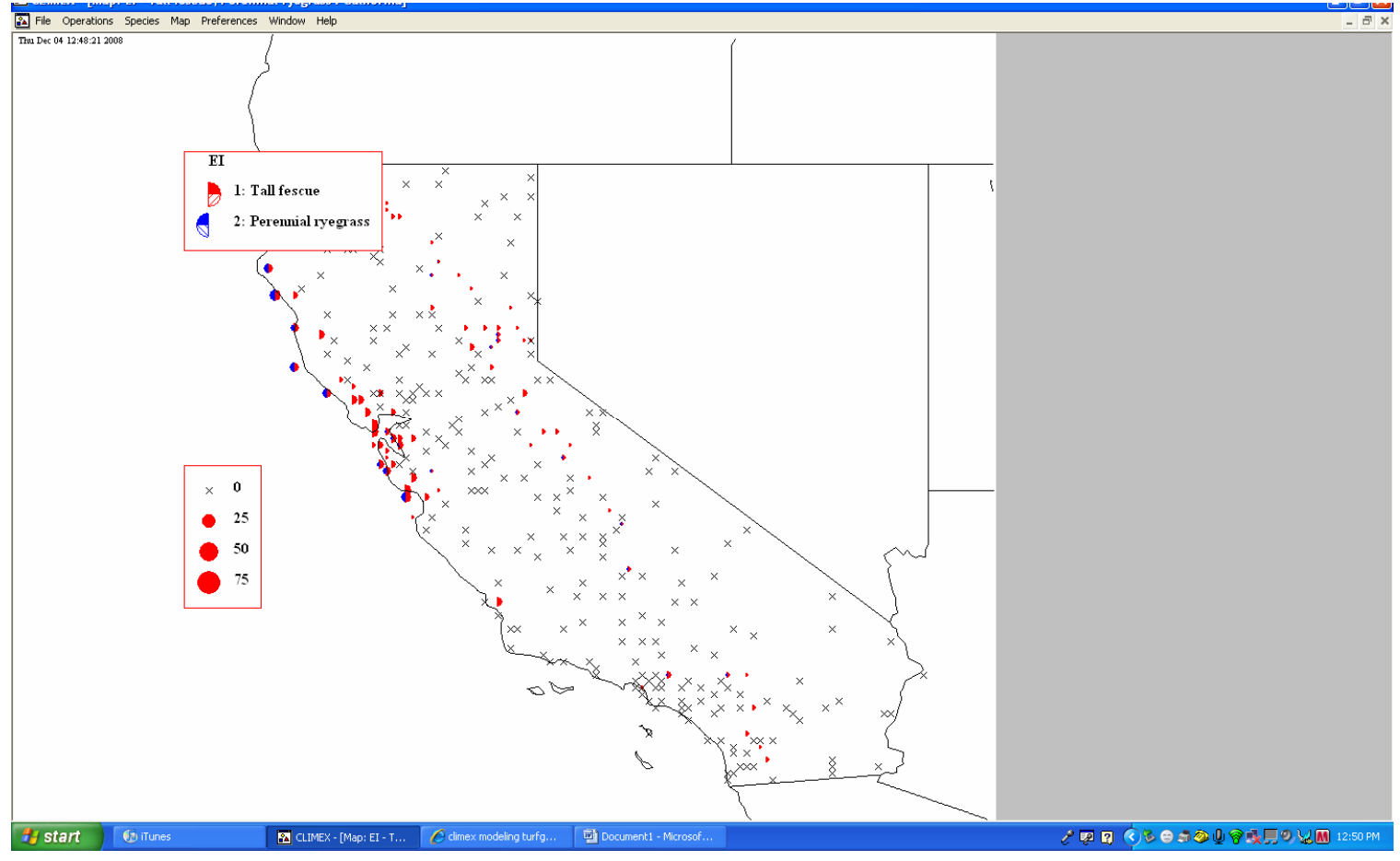

The distribution of tall fescue and perennial ryegrass is shown in California with the irrigation term turned on (Figure 1-2). This model shows the distribution of 
the grasses when water is not the limiting factor. This model showed that both tall fescue and perennial ryegrass could grow in many more areas.

Figure 1-2. Tall fescue and perennial ryegrass irrigated CLIMEX ${ }^{\mathrm{TM}}$ model of California

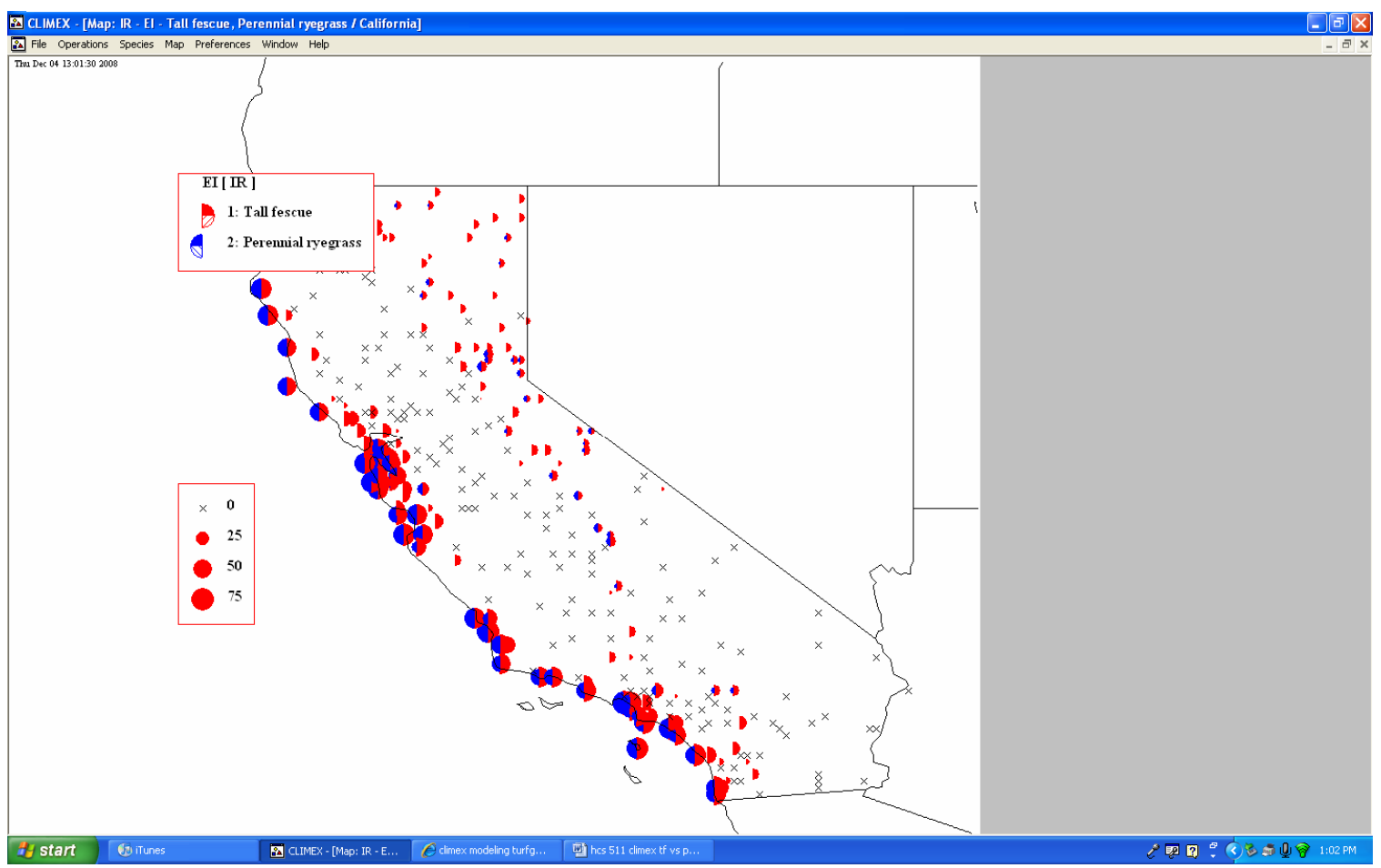

CLIMEX ${ }^{\mathrm{TM}}$ can be a strong tool in predicting where grasses should be used.

The unirrigated model is the best predictor of where we should grow certain grasses.

If the model predicts that a grass can be grown without irrigation, then the plant should be well adapted for that area. A well adapted turfgrass will need fewer resources, especially water.

One point to mention is the irrigation term. Usually for turfgrasses, managers irrigate to prevent wilt. This is why the 'blanket' irrigation term used is not useful solely for this manual. There is an interaction between irrigation and heat. In turfgrasses, irrigation actually reduces the canopy temperature. 


\section{Endophyte infection}

In the years following the release of 'Kentucky 31', the use of tall fescue has grow significantly. Soon after its introduction, ranchers noticed toxicity problems in livestock grazing tall fescue. Research showed that tall fescue was host to an endophytic fungus (Neotyphodium coenophialum) found inside the sheath. Although the endophyte causes harm to the livestock, it actually improves drought and grazing tolerance, water and nitrogen use efficiency, and resistance to some pest. In some way, this fungus has improved the growth and competitiveness of tall fescue (Rochefort, et al., 2007).

Studies have shown that tall fescue plants infected with the endophyte also exhibit increased tolerance to climatic factors such as drought and high temperatures (Bacon, 1993). The mechanism for this trait is not very well understood, however, it is thought that hormonal changes occur as a result of the infection of the endophyte thus causing changes in osmotic pressure within the plant cells (Neotyphodium and the Grass endophytes, University of Sydney, 2008).

Another reason for more drought tolerance is the greater root and tiller numbers due to enhanced vigor of the infected plant (Endophyte infected grasses, University of Rhode Island, 2008). However, a 1992 study found that there was no significant difference in drought tolerance between infected and non-infected cultivars of Tall fescue (White, et al., 1992). 


\section{Classification}

Tall fescue (Lolium arundinaceum (Schreb.) S.J. Darbyshire) is classified within the Poaceae family. This large family consists of over 500 genera and 8,000 species. (Flowering Plant families, 2007). Within this family, many economically important crops such as sugarcane, wheat, corn, and rice are found.

There has been much debate about the classification of Tall fescue. Previously, tall fescue was known as Festuca arundinaceae. This classification in both the Festuca and Lolium (ryegrass) genus arises from the conflicting characteristics of tall fescue (Hoveland, undated). The Festuca-Lolium complex, as it is commonly referred to, presents a unique problem to taxonomist because taxonomy based on morphological characteristics often conflicts with observed fertility relationships as well as many biochemical and molecular considerations. For instance, the flowers of the genera are vastly different. Morphologically, Festuca has a paniculate inflorescence with a lower glume (Darbyshire, 1993) as compared to the spike type inflorescence of the genus Lolium.

\section{Genetics}

In this complex, different species of grasses may have the ability to interbreed. Some hybrids from morphologically different parents within this complex actually exhibit increased growth and competitiveness compared to parents with morphologically identical characteristics. This phenomenon is called "hybrid vigor" (Craven, et al. , 2007). Although the name has been officially changed, the old name Festuca arundinaceae is still widely used in current literature. 
Tall fescue has a very complex genotype. Generally a hexaploid, although other ploidy levels have been reported, tall fescue has a high adaptive potential as polyploids tend to have higher survivability of chromosome deviation than diploids.

Asexual reproduction by tillering may also play a part in tall fescue's adaptive ability (Kasperbauer, 1990). These adaptive mechanisms have made tall fescue very evolutionarily efficient. Tall fescue has also been able to change and adapt as environmental conditions change, evidenced by tall fescue's ability to exploit new niches. Not only has this created success in tall fescue evolution, but is found in other grasses as well (Craven et al., 2007).

According to Oregon State's Tall Fescue Information System, complex genetics tend to break many of the rules of taxonomy and is constantly changing to the environment around them. There are currently over 160 different cultivars of tall fescue of which approximately 90 are commercially available (National Turfgrass Evaluation Program, 2007). This high number of cultivars exemplifies the drive to find premium tall fescue cultivars.

\section{General characteristics}

Tall fescue is a perennial, cool-season turfgrass (Beard, 2002). Although tall fescue persists year round, there are specific growing seasons for best quality. In the case of tall fescue, the two most active growing seasons are in the spring and fall. In the central California coastal region, temperatures in March/April and October historically are nearest the optimal growing temperature for this C3 species (18$24^{\circ}$ Celsius) (Oregon State University, 2007). 
Tall fescue is a bunch type grass as it develops and spreads only by intravaginal tillering at or near the soil surface. Some, however, believe tall fescue produces very short horizontal shoots that may be rhizomes (Beard, 2002). In recent years, breeders have selected tall fescue cultivars with longer, more vigorous rhizome type tillers. The benefits being faster, more vigorous lateral growth and increased wear tolerance due to increased thatch and secondary regrowth structures.

Anatomically, tall fescue has rolled vernation; an approximately two millimeter membraneous ligule; short (0.5-1.5 millimeter), blunt, pubescent auricles; and a broad collar (Turgeon, 2005). The inflorescence of tall fescue is a contracted panicle.

Tall fescue is easily identified by the coarse vertical ridging present on the leaf blades. In general, the leaf blades of mowed tall fescue are three to eight millimeters in width, making it thicker and coarser than most other cool-season grasses. Recently, plant breeders have developed cultivars of tall fescue with finer textures similar to perennial ryegrass (Ray, et al., 2007).

The roots of tall fescue are fibrous and can reach depths of 100 centimeters producing a tremendous amount of biomass. In a field study at Kansas State University, it was found that tall fescue had summer leaf wilt resistance equivalent to that of bermudagrass, a warm season grass with a relatively high wilt resistance (Qian, et al. 1997).

\section{Management Practices}

Because the crown of tall fescue is somewhat elevated, care should be taken not to mow below the leaf collar. Lower mowing heights may result in the removal 
of the apical meristem which is located higher within the crown than many other turfgrasses (Beard, 2002). Generally, the recommended mowing height of tall fescue is six to ten $\mathrm{cm}$. Mowing should not ever drop below five centimeters.

As tall fescue does not produce a lot of vegetation it requires a moderate amount of fertility compared to other cool-season grasses. It will tolerate little to no fertilization, but optimally tall fescue performs best with 151 to 201 kilograms of nitrogen per hectare per year (Beard, 2002). Compared to other cool-season grasses, this rate is low.

Perennial ryegrass, on the other hand, requires much higher rates of annual nitrogen, usually about 252 to 303 kilograms of nitrogen per hectare per year (Turgeon, 2005). In a study that compared tall fescue, perennial ryegrass, and Kentucky bluegrass (Poa pratensis) grown with the same amount of nitrogen, tall fescue had the overall best year-round turf quality ratings (Walker et al., 2007).

Economically, the cost difference of applying 101 to 151 more kilograms of nitrogen per hectare per year could be significant. One hundred one kilograms of nitrogen per hectare translates into 87 pounds per acre. Considering that an average golf course has 24 hectares of rough, the total added amount of nitrogen would be about 2,424 kilograms representing thousands of dollars of added cost per year.

Besides the cost difference, the detrimental effects of higher rates of nitrogen can include ground water leaching, leaf succulence, and possibly increased activity of unwanted weeds and diseases. In a study at the University of Georgia, it was found that increased nitrogen caused higher activity of brown patch (Rhizoctonia solani) (Burpee, 1995). It has also been shown that as much as six percent of the total 
nitrogen supplied to turf may be leached into ground water (Erickson et.al., 2001). If the yearly approximation of 2,424 kilograms of nitrogen is used that would mean that 145 kilograms of nitrogen could possibly be leached into ground water per year.

Tall fescue shows good heat and drought tolerance. As a result, tall fescue performs better with deep and less frequent irrigation. Data has shown that this management philosophy can produce deeper root systems allowing the plant draw water from deeper within the soil profile (Richie et al., 2002). Irrigation frequency is the superior factor as it relates drought and heat tolerance. In comparison with Kentucky bluegrass (Poa pratensis) and perennial ryegrass (Lolium perenne), tall fescue is more drought tolerant (Turgeon, 2005).

Cultivar type or mowing height has not been shown to make a significant difference with stress tolerance. The deeper rooting of tall fescue enables water extraction from deeper in the soil profile resulting in minimal impact on transpiration. If transpiration can continue under drought conditions, canopy temperature should remain stable (Ervin et.al., 1998).

Mowing height has been shown to affect turf quality, however. Lower mowing heights within a given species adapted range tend to produce better overall turf quality ratings, especially density and texture, as compared to the higher mowing heights. Genetic plant color tends to differ less with mowing height than with fertility or plant health (Richie, et.al., 2002).

Under normal conditions, tall fescue is relatively pest and disease free. However, under excess irrigation or rainfall, brown patch (Rhizoctonia spp.) and leaf spot (Helminthosporium spp.) can become problematic. 
Brown patch is the most common fungal disease in tall fescue. Symptoms include circular brown patterns that can range from seven centimeters to 2.5 meters and a characteristic grey "smoke ring" at the leading edge of the patch. Tan colored lesions are often visible on the leaf blade as well as the presence of mycelium in wet, moist conditions. This disease is most abundant during long periods of warm, humid weather as the disease requires 10-12 hours of leaf wetness to develop.

Brown patch can be controlled culturally by increasing air movement, decreasing irrigation, increasing soil drainage, and decreasing summer nitrogen applications. Chemical controls include many broad spectrum fungicides such as propiconazole or chlorothalonil (Tredway, 2005).

Lastly tall fescue is one of the more salt-tolerant cool-season turfgrasses. As more regulations are imposed concerning water use, a majority of potable water sources will go for human use and consumption. This leaves turfgrass managers having to use water from secondary sources such as sewage effluent reuse and well water. Reuse water is often high in salts, (both carbonates and bicarbonates) which can result in the dehydration of leaf tissue. Saline conditions may also cause potassium to become deficient as the sodium reduces potassium acquisition (Taiz, et al., 2006).

Compared to Kentucky bluegrass, tall fescue tolerates saline conditions much better. In Kentucky bluegrass, salinity causes root cortex cells to collapse at 14.1 $\mathrm{dSm}-1$ whereas in tall fescue, it took $23.5 \mathrm{dSm}-1$ for root cortex cells to collapse (Alshammary, et al., 2004).

\section{Chapter 2: Field Study}




\section{Introduction}

This project was designed to investigate 18 tall fescue cultivars grown at two different mowing heights (five and $10 \mathrm{~cm}$ ) to evaluate each for density, texture, and color. Cultivars were chosen by looking at the best performers from the latest National Turfgrass Evaluation Program (NTEP) for tall fescue in the transition zone region. The best 18 cultivars were chosen for this study.

Turfgrass evaluation is not new to the industry. The NTEP is the leader in turfgrass evaluation but smaller projects are always adding to the literature. This experiment will follow many of the same protocols of the NTEP trials as well as the tall fescue trial performed at the University of California at Riverside (Richie, et al.,2002) and New Mexico State University (Ray, et al.,2007).

We believe this project is important for two reasons. First, it will determine important characteristics within selected tall fescue cultivars grown in the central California coastal region mowed at both five and 10 centimeters . This information will provide golf course superintendents with alternative choices for golf course rough areas with little impact to quality or playing conditions. Currently, perennial ryegrass is the choice for these playing areas. It will also help homeowners and landscapers choose cultivars best suited to their conditions.

Second, the project will demonstrate any variation between cultivars of tall fescue as it relates the impact of mowing on density, texture, and color. This will help determine not only which tall fescue cultivar to use, but also the best mowing strategy. 


\section{$\underline{\text { Material and Methods }}$}

This study was conducted in 2007 and 2008 on the research plots at the southern boundary of the California Polytechnic State University-San Luis Obispo Environmental Horticulture Science unit. This area was previously used for weed research and was planted to a cover crop of annual grasses and vetch. An application of Roundup Pro ${ }^{\mathrm{TM}}$ (EPA Reg. \# 524-475) at the rate of two percent was applied to the area using a Toro MultiPro Boom ${ }^{\mathrm{TM}}$ Sprayer.

This area had an original slope of $10 \%$. Fill was added to bring the final slope to approximately $1-2 \%$ to facilitate drainage and a good planting bed. The soil was top soil purchased from San Luis Soil and Sod Farm located in San Luis Obispo. The top soil is a Chualar sandy clay loam with a $\mathrm{pH}$ of 7.3 and approximately $4 \%$ organic matter. The Munsell color of the soil is very dark grayish brown (10 YR 3/2). Once final grade was achieved, irrigation was installed to uniformly distribute water on the $35 \mathrm{~m} \times 12.2 \mathrm{~m}$ plots using Hunter ${ }^{\mathrm{TM}}$ PGM 100 heads.

The objective of this study was to examine the performance of 18 different tall fescue cultivars maintained at 2 different mowing heights of 5 and 10 centimeters (Figure 2-1). The plots were mowed twice weekly with a walk behind rotary mower. 
Figure 2-1. Tall fescue cultivars and sponsors used in this experiment.

\begin{tabular}{|l|l|}
\hline Cultivar & Sponsor \\
\hline Corgi & DLF International Seeds \\
\hline Coyote II & Scotts \\
\hline Escalade & Oregrow Seeds \\
\hline Falcon IV & Proseeds Marketing \\
\hline Fidelity & Pure Seed Testing Inc \\
\hline Finelawn Elite & Proseeds Marketing \\
\hline Greenskeeper WAF & Scotts \\
\hline Gremlin & Proseeds Marketing \\
\hline Houndog 6 & DLF International Seeds \\
\hline Inferno & Jacklin Seeds by Simplot \\
\hline Justice & Pennington Seed Inc \\
\hline Magellan & Burlingham Seeds \\
\hline PST-5HD & Pure Seed Testing Inc \\
\hline Rebel Exeda & Pennington Seed Inc \\
\hline RTF & Barenbrug USA \\
\hline R4 & Budd Seed \\
\hline Scorpion II & Proseeds Marketing \\
\hline Turbo & Burlingham Seeds \\
\hline
\end{tabular}


Plot design was a randomized block design throughout and replicated 5 times. Each cultivar was randomly placed to a plot. The mowing height was stripped for ease of mowing (Figure 2-2). Plots were seeded at the rate of 3.2 kilograms of seed per 93 square meters on August 14, 2007.

Figure 2-2. Plot layout with solid lines indicating cultivar and dotted line indicating mow height
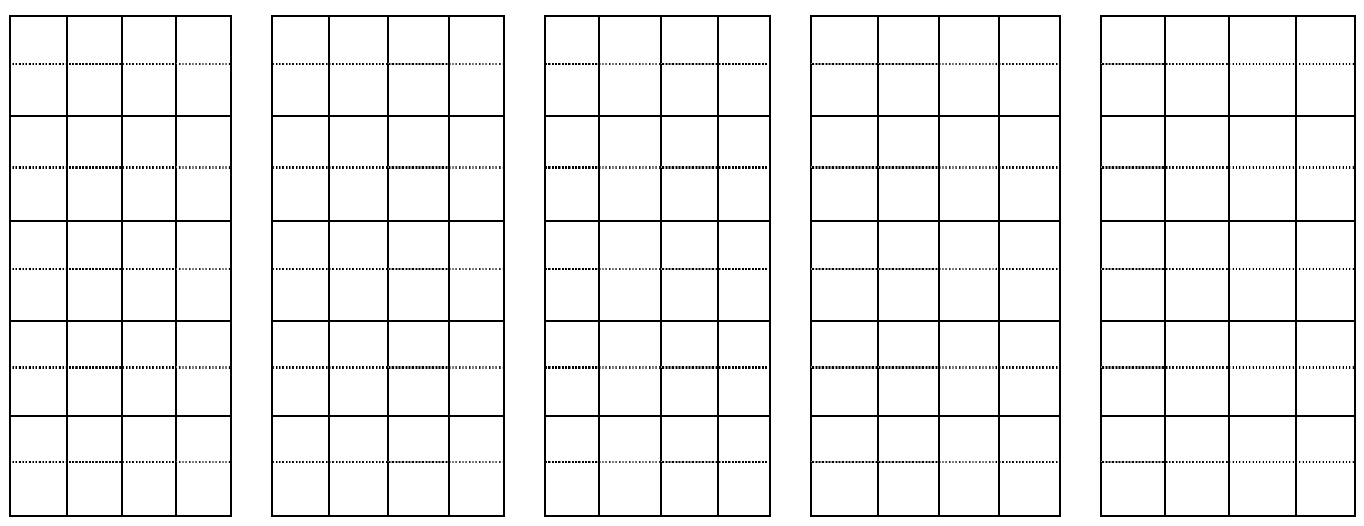

On October 15, 2007 all plots were grown-in to sufficient ground coverage and plant height. Mowing was then initiated. A two week period was given for the grasses to acclimate to the mowing heights. Plots were mowed at either five or 10 centimeters throughout the experiment.

For the initial part of our study, observations for plant quality and plant health were taken monthly from November 2007 until August 2008. Specific variables for plant quality include genetic color, leaf texture, and stand density. These observations were taken for each cultivar as well as each mowing height within the cultivar. Each month, 10 students were used to give turf quality ratings. Each student was told exactly how to rate the turfgrass and were given examples of ratings. When the data was analyzed the mean of all 10 students was used. This study relied heavily 
on multiple empirical observations used to calculate means for each of the quality components.

Genetic plant color was observed visually by giving a numerical rating to plant color. This rating used a 1-9 scale ( $1=$ straw brown, $9=$ dark green). Necrotic plant material was not taken into account on this measure as we were looking to isolate genetic plant color specifically.

Leaf texture was observed visually by looking at leaf width of a fully expanded leaf. Visual observation used a 1-9 scale (1=very coarse, $9=$ very fine).

Stand density was observed visually by looking at the number of individual plants within the given area. A visual rating scale of 1-9 was used (1=no grass cover, $9=100 \%$ cover $)$.

Overall plant health was also monitored. The variables were the presence of diseases and insects. Disease activity was recorded on a 1-9 scale (1=no disease, $9=$ complete plant necrosis due to disease). It was noted which disease was present but historically, brown patch is the most frequent disease on tall fescue in this region. Insect damage was also recorded on a 1-9 scale $(1=$ no insect damage, $9=$ plant necrosis due to insects). Insect damage was the predictor for insect presence because often insects must be in high populations before showing any damage to turfgrass. The type of insect present was noted.

Irrigation practices varied seasonally but were the same throughout all plots. Fertilization was administered as shown in Figure 2-3. This schedule provided plots with 1.8 kilograms of nitrogen per 93 square meters per year. 
Figure 2-3. Fertilization schedule.

\begin{tabular}{|c|c|c|}
\hline Date & Rate (kg of N/93 sq m) & Source \\
\hline 15-Apr-07 & 0.45 & $19-6-12 \mathrm{w} / 50 \%$ Polyon \\
\hline 15-May-07 & 0.45 & $19-6-12 \mathrm{w} / 50 \%$ Polyon \\
\hline 15-Sep-07 & 0.45 & $22-2-22 \mathrm{w} / 15 \%$ Polyon \\
\hline 15-Feb-08 & 0.45 & $22-2-22 \mathrm{w} / 15 \%$ Polyon \\
\hline 15-Apr-08 & 0.45 & $19-6-12 \mathrm{w} / 50 \%$ Polyon \\
\hline 15-May-08 & 0.45 & $19-6-12 \mathrm{w} / 50 \%$ Polyon \\
\hline 15-Sep-08 & 0.45 & $22-2-22 \mathrm{w} / 15 \%$ Polyon \\
\hline
\end{tabular}

All data were sorted and analyzed using Minitab® Statistical Software 15.

First, the average from the 10 students was calculated to give us a single number. Next, the data was sorted into individual by months. An ANOVA test was run for each month to see whether there was a significant difference in plant quality. The interaction term of cultivar*mowing height was looked at to show means between cultivars grown at each specific mowing height (ie. Cultivar 1 vs. Cultivar 2 both at two inch mowing height) and also to determine if mowing height had a significant effect on the cultivar (ie. Cultivar 1 at five $\mathrm{cm}$ mowing height vs. Cultivar 1 at $10 \mathrm{~cm}$ mowing height). Figures were created to show the p-values of the interaction term of cultivar*mowing height. If $\mathrm{p}=$ values were significant at $\alpha=0.05$, Tukey's multiple comparison was used to see which specific cultivar at what mowing height were significant different. This data will enable the reader to see how each cultivar performed under different mowing conditions and how they compared to each other. 


\section{$\underline{\text { Results and Discussion }}$}

\section{Density}

As Table 2-1 shows, the interaction term between cultivar and mowing height was only significant in May and July of 2008. All other months were insignificant. For those two months, Tukey's comparison was used to see which cultivars were significantly different.

Table 2-1. Density P-values

\begin{tabular}{|r|c|c|c|}
\hline DATE & $\begin{array}{l}\text { Cultiv } \\
\text { ar }\end{array}$ & $\begin{array}{l}\text { Mow } \\
\mathrm{Ht}\end{array}$ & $\begin{array}{l}\text { Culti x Mow } \\
\text { ht }\end{array}$ \\
\hline $\begin{array}{r}\text { Nov- } \\
07\end{array}$ & 0.003 & 0.020 & NS \\
\hline $\begin{array}{r}\text { Dec- } \\
07\end{array}$ & 0.000 & NS & NS \\
\hline Jan-08 & 0.000 & NS & NS \\
\hline Feb-08 & 0.000 & NS & NS \\
\hline Mar-08 & NS & NS & NS \\
\hline Apr-08 & 0.002 & NS & NS \\
\hline $\begin{array}{r}\text { May- } \\
08\end{array}$ & 0.000 & 0.044 & 0.001 \\
\hline Jun-08 & 0.000 & NS & NS \\
\hline Jul-08 & 0.000 & NS & 0.004 \\
\hline $\begin{array}{r}\text { Aug- } \\
08\end{array}$ & 0.000 & 0.000 & NS \\
\hline
\end{tabular}

In May 2008, there were many significances of average density at $\alpha=0.05$.

Cultivars 1 (Greenskeeper WAF), 3 (Escalade), and 9 (Inferno) grown at five $\mathrm{cm}$ had a significantly lower average density rating than cultivars 11 (PST-5HD), 12 (Fidelity), and 15 (Finelawn Elite). Furthermore, cultivar 9 (Inferno) had a significantly lower density than cultivar 10 (Coyote II) and 17 (Magellan). Also at the five $\mathrm{cm}$ mowing height, cultivars 2 (Justice), 5 (R4), and 7(Houndog 6) was significantly higher than cultivar 9 (Inferno). At the $10 \mathrm{~cm}$ mowing height, cultivar 1 
(Greenskeeper WAF) had a significantly lower average density rating than cultivars, 2 (Justice), 4 (Corgi), 5 (R4), 10 (Coyote II), 12 (Fidelity), 14 (Turbo), 15 (Finelawn

Elite), and 17 (Magellan). Also, cultivar 9 (Inferno) was significantly lower than cultivars 2 (Justice), 10 (Coyote II), and 14 (Turbo). Lastly, at $10 \mathrm{~cm}$ cultivar 14

\begin{tabular}{|c|c|c|}
\hline $\begin{array}{r}\mathrm{Ma} \\
\mathrm{y}-08\end{array}$ & $\begin{array}{l}5 \\
\mathrm{~cm}\end{array}$ & $\begin{array}{l}1 \text { (Greenskeeper WAF), } 3 \text { (Escalade), } 9 \text { (Inferno) < } 11 \text { (PST-5HD), } 12 \\
\text { (Fidelity), } 15 \text { (Finelawn Elite) }\end{array}$ \\
\hline & & 9 (Inferno) < 10 (Coyote II), 17 (Magellan) \\
\hline & & 9 (Inferno) < 2 (Justice), 5 (R4), 7 (Houndog 6) \\
\hline & $\begin{array}{l}10 \\
\mathrm{~cm}\end{array}$ & $\begin{array}{l}1 \text { (Greenskeeper WAF) < } 2 \text { (Justice), } 4 \text { (Corgi), } 5 \text { (Coyote II), } 12 \\
\text { (Fidelity), } 14 \text { (Turbo), } 15 \text { (Finelawn Elite), } 17 \text { (Magellan) }\end{array}$ \\
\hline & & 9 (Inferno) < 2 (Justice), 14 (Turbo) \\
\hline & & 18 (Scorpion) < 14 (Turbo) \\
\hline
\end{tabular}

(Turbo) was significantly higher than cultivar 18 (Scorpion) (Table 2-2).

Table 2-2. Density ratings for May 2008 at given mow height.

In July 2008, there were differences between average stand density within both five and $10 \mathrm{~cm}$ mowing height. In the five $\mathrm{cm}$ mowing height, cultivar 3 (Escalade) had a significantly lower average stand density rating than cultivar 14 (Turbo). In the $10 \mathrm{~cm}$ mowing height, cultivar 8 (Gremlin) had a significantly lower average stand density rating than cultivars 2 (Justice) and 4 (Corgi) (Table 2-3).

Table 2-3. Density ratings for July 2008 at given mow height

\begin{tabular}{|l|l|l|}
\hline Jul-08 & $5 \mathrm{~cm}$ & 3 (Escalade) $<14$ (Turbo) \\
\hline & $10 \mathrm{~cm}$ & $\begin{array}{l}8 \text { (Gremlin) }<2 \text { (Justice) } 4 \\
\text { (Corgi) }\end{array}$ \\
\hline
\end{tabular}

Over the year, there were not many overall trends in stand density between cultivars within a mowing height. Cultivar 1 (Greenskeeper WAF),cultivar 3 (Escalade), and cultivar 9 (Inferno) seemed to show up with lower overall stand 
density ratings than the other cultivars at both the five and $10 \mathrm{~cm}$ mowing heights. No cultivar stood out as to having exceptional average stand density. Also, there were no significant differences in average stand density between mowing height within a cultivar.

Also of note was the overall mean of the mowing heights (Figure 2-4). In general, the shorter mowing height had better average densities which are in unison with the literature (Grossi, et. al., 2004; Richie, et al., 2002). P-values below 0.05 indicate significant differences between mowing heights. Also, the pattern in which density varied is predictable. The average density got higher after the first full growth period with a spiking in April which had ideal growing conditions for tall fescue.

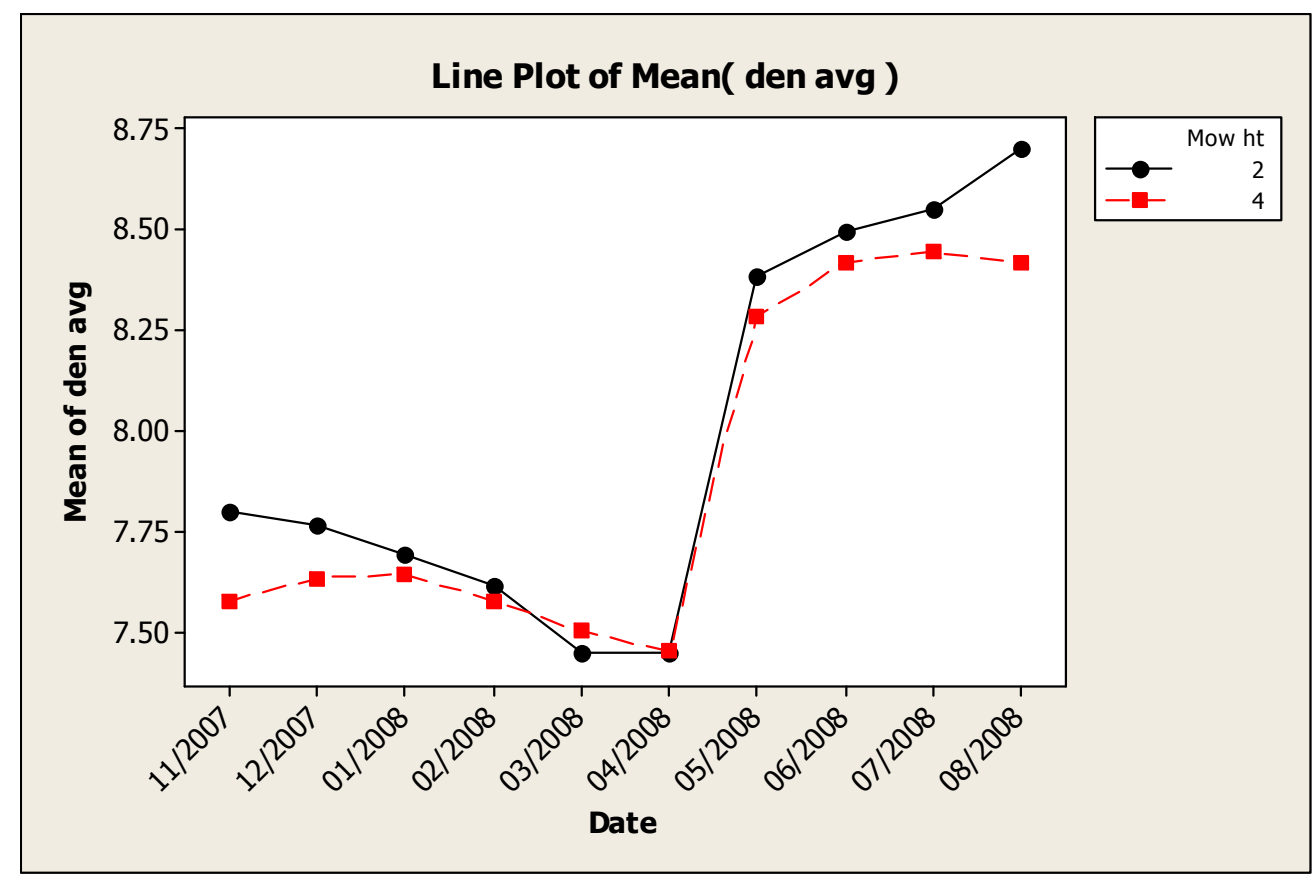

Figure 2-4. Mean densities by mowing height over time. Significant difference between mowing height in November, May, and August 


\section{Texture}

No measurements for leaf texture were taken for the months of November, December, and January. During this time period, no difference in plant texture was observed between any cultivars or mowing heights (data not shown).

The interaction term between cultivar and mowing height was only significant on February of 2008. All other months, the interaction was insignificant. (Table 2-4).

Table 2-4. Texture P-values

\begin{tabular}{|c|c|c|c|}
\hline DATE & $\begin{array}{c}\text { Cultiv } \\
\text { ar }\end{array}$ & $\begin{array}{c}\text { Mow } \\
\mathrm{Ht}\end{array}$ & $\begin{array}{c}\text { Culti } \times \text { Mow } \\
\text { ht }\end{array}$ \\
\hline Nov-07 & NA & NA & NA \\
\hline Dec-07 & NA & NA & NA \\
\hline Jan-08 & NA & NA & NA \\
\hline Feb-08 & 0.001 & NS & 0.014 \\
\hline Mar-08 & 0.003 & NS & NS \\
\hline Apr-08 & 0.003 & NS & NS \\
\hline May-08 & 0.000 & NS & NS \\
\hline Jun-08 & 0.000 & NS & NS \\
\hline Jul-08 & 0.000 & NS & NS \\
\hline Aug-08 & 0.000 & NS & NS \\
\hline
\end{tabular}

In February 2008, there were significant differences at $\alpha=0.05$ between cultivars at the five $\mathrm{cm}$ mowing height. Cultivar 14 (Turbo) at five $\mathrm{cm}$ was significantly better than cultivars 4 (Corgi), 5 (R4), 8 (Gremlin), 10 (Coyote II), 11 (PST-5HD), 13 (Falcon IV), and 16 (Rebel Exeda). No other comparisons were significantly different (Table 2-5).

Table 2-5. Texture ratings for February 2008 at given mowing heights. 


\begin{tabular}{|l|l|l|}
\hline & & $\begin{array}{l}14 \text { (Turbo) }>4 \text { (Corgi), } \\
\text { (R4), 8 (Gremlin), 10 } \\
\text { (Coyote II), 11 (PST-5HD), } \\
13 \text { (Falcon IV), 16 (Rebel } \\
\text { Exeda) }\end{array}$ \\
\hline Feb-08 & $5 \mathrm{~cm}$ & \\
\hline
\end{tabular}

There are very little differences in leaf texture. There was only one month where the interaction term was significant. With only one month being significant, it is impossible to draw any conclusions except that there are no differences between the interaction term on leaf texture. With another years worth of data there may be a trend that develops. Also, as the plant starts to mature, there may be more recognizable differences between leaf texture ratings.

When looking at the overall affect of mowing height on average plant texture, mowing height is not having an affect on average plant texture (Figure 2-5). This is contrary to a study that showed that lower mowing heights led to more favorable leaf texture ratings (Grossi et al., 2004). I believe that we saw the results we did because the difference in mowing height was too small. If we had implemented a higher mowing height, I think we would have seen greater differences in average plant texture rating. 


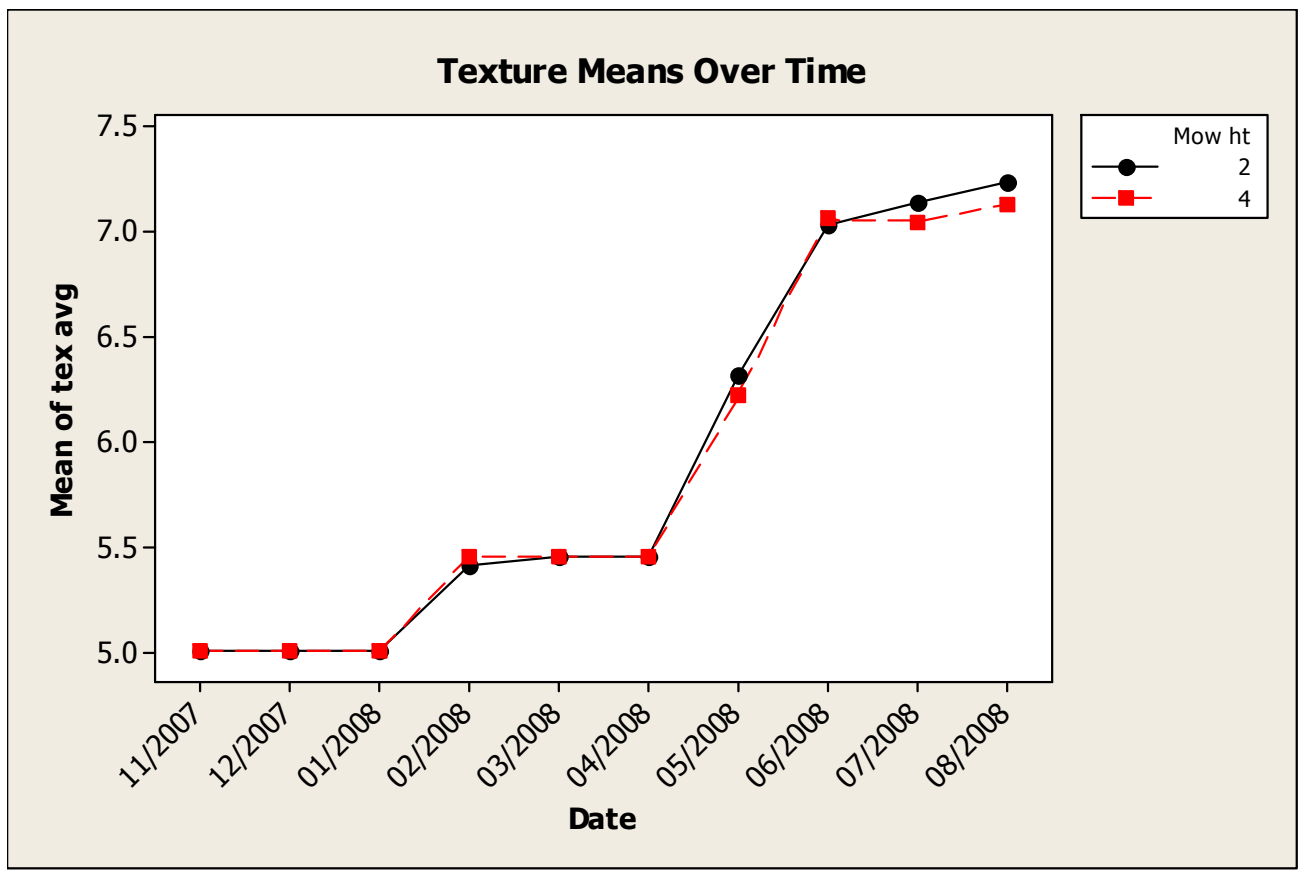

Figure 2-5. Mean leaf texture by mowing height over time. No mowing heights significantly different for given month.

This also shows how texture was differing over time (Figure 2-5). It seems that texture may have a correlation with plant maturity. It will be interesting to see if this trend continues in the second year of the study.

\section{Genetic Plant Color}

The interaction term of cultivar and mowing height was significant for genetic plant color on May and August of 2008. Tukey's comparison was used to determine which cultivars at what mowing height was significantly different (Table 2-6). 
Table 2-6. Genetic plant color p-values

\begin{tabular}{|c|c|c|c|c|}
\hline DATE & $\begin{array}{l}\text { Cultiv } \\
\text { ar }\end{array}$ & $\begin{array}{l}\text { Mow } \\
\mathrm{Ht}\end{array}$ & $\begin{array}{l}\text { Culti x } \\
\text { Mow } \\
\text { ht }\end{array}$ & \\
\hline $\begin{array}{r}\text { Nov- } \\
07\end{array}$ & 0.020 & NS & NS & \\
\hline $\begin{array}{r}\text { Dec- } \\
07\end{array}$ & 0.036 & NS & NS & \\
\hline Jan-08 & 0.049 & NS & NS & \\
\hline Feb-08 & 0.000 & 0.047 & NS & \\
\hline Mar-08 & 0.001 & NS & NS & $\begin{array}{l}\text { ***Block sig } \\
\text { dif }\end{array}$ \\
\hline Apr-08 & 0.006 & NS & NS & \\
\hline $\begin{array}{r}\text { May- } \\
08\end{array}$ & 0.000 & NS & 0.039 & \\
\hline Jun-08 & 0.007 & 0.000 & NS & \\
\hline Jul-08 & 0.000 & NS & 0.024 & \\
\hline $\begin{array}{r}\text { Aug- } \\
08 \\
\end{array}$ & 0.000 & 0.000 & NS & \\
\hline
\end{tabular}

In May 2008,

there were differences in genetic plant color. At the five $\mathrm{cm}$ mowing height, cultivars 4 (Corgi) and 9 (Inferno) were significantly lower than cultivars 13 (Falcon IV) and 15 (Finelawn Elite). Furthermore, cultivar 4 (Corgi) was significantly lower than cultivar 12 (Fidelity). Average genetic color at the $10 \mathrm{~cm}$ mowing height was also significant. Cultivars 1 (Greenskeeper WAF) and 2 (Justice) had significantly higher average genetic color ratings than cultivars 4 (Corgi) and 9 (Inferno) (Table 2-7).

Table 2-7. Genetic plant color ratings for May 2008 at given mow height.

\begin{tabular}{|l|l|l|} 
U8 & $5 \mathrm{~cm}$ & (IInelawn tIITe), \\
\hline & & 9 (Inferno) < 13 (Falcon IV), 15 (Finelawn Elite) \\
\hline & $10 \mathrm{~cm}$ & $\begin{array}{l}4 \text { (Corgi), } 9 \text { (Inferno) }<1 \text { (Greenskeeper WAF), } \\
2 \text { (Justice) }\end{array}$ \\
\hline
\end{tabular}


In July 2008, average genetic color ratings had significant differences within both mowing heights. At the five $\mathrm{cm}$ mowing height, cultivars 12 (Fidelity) and 13 (Falcon IV) had significantly higher average genetic color ratings than cultivar 16 (Rebel Exeda). Further more, cultivar 12 (Fidelity) also had a higher average genetic color rating than cultivar 18 (Scorpion). At the $10 \mathrm{~cm}$ mowing height, cultivars 6 (RTF), 10 (Coyote II), and 11 (PST-5HD) had a significantly lower average genetic plant color rating than cultivar 16 (Rebel Exeda) (Table 2-8).

Table 2-8. Genetic plant color ratings for July 2008 at given mow height.

\begin{tabular}{|l|l|l|}
\hline Jul-08 & $5 \mathrm{~cm}$ & $\begin{array}{l}16 \text { (Rebel Exeda) }<12 \text { (Fidelity), } 13 \text { (Falcon } \\
\text { IV) }\end{array}$ \\
\hline & & 18 (Scorpion) < 12 (Fidelity) \\
\hline $10 \mathrm{~cm}$ & $\begin{array}{l}\text { 6 (RTF), 10 (Coyote II), } 11 \text { (PST-5HD) }<16 \\
\text { (Rebel Exeda) }\end{array}$ \\
\hline
\end{tabular}

Throughout the 10 months, there were minimal patterns in the average genetic color. Although there were some differences, no pattern could be found. No cultivar at a specific mowing height stood out among the others for superior genetic plant color. Hopefully with a second years worth of data some patterns will be found. When looking at data comparing the affect of mowing height on average genetic color, there were some interesting patterns (Figure 2-6). We found that mowing height does not have an effect on average genetic color. Also of note, is the spike between March and April. This time followed a fertilization as well as having ideal growing conditions that led to the jump in average genetic color ratings. This jump was to be expected because higher average color ratings are directly correlated to higher nitrogen rates (Walker et. al., 2007). 


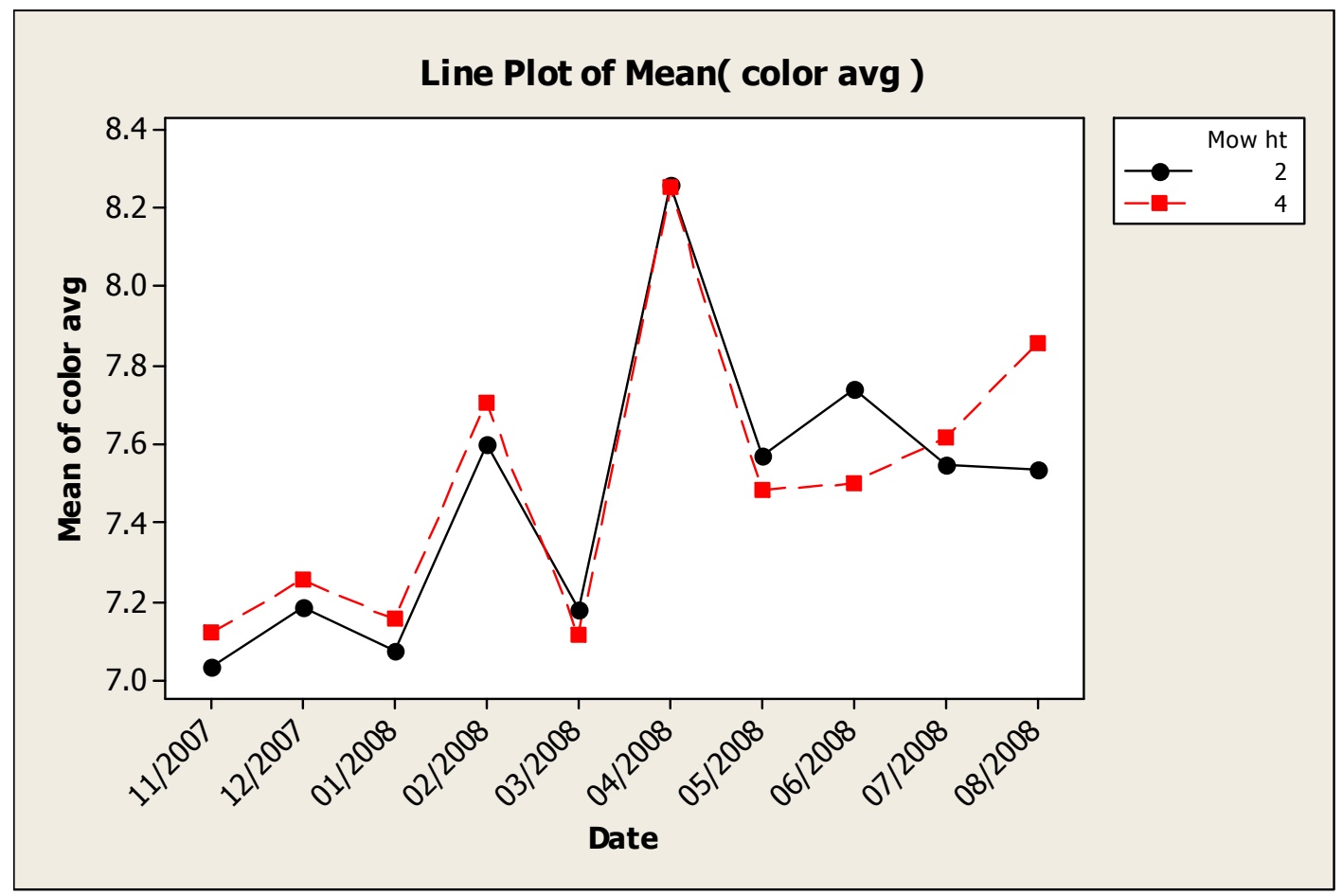

Figure 2-6. Mean genetic color by mowing height over time. Mowing height between 2 and 4 significantly different on February, June, and August.

\section{Plant Health}

Throughout the experiment overall plant health was never compromised.

Zero insect activity was noticeable on the turf as well as zero disease (data not shown). This can be attributed to good management practices, especially irrigation and fertility. The role of the endophyte may also play a role in zero insect activity. 


\section{$\underline{\text { Conclusion }}$}

Although some interesting trends were found, there were not many significant differences found within the data for the first year. This study may show that there are not very many differences in the turf quality indicators of density, texture, and color between cultivars grown at a given mowing height. Also, there was no significant difference for a turf quality indicator between mowing heights for a given cultivar between the five and 10 centimeter mowing heights.

The results of this experiment did agree with the literature on some points. Average stand density ratings were generally higher for cultivars grown at five centimeters than those grown at 10 centimeters. Also, genetic plant color was directly correlated to the application of nitrogen fertilizer.

There may be a reason there where few significant differences between treatments in this experiment. These 18 cultivars were each selected from the NTEP trials for the transition zone region and all 18 were top performers. As they were the top 18 cultivars, there may be little to no difference between them that is significant.

Another reason for the little significant differences in this experiment is the lack of genetic variation within the species. For many years scientist have been selecting for superior tall fescue traits. There is a possibility that tall fescue has reached its genetic threshold and there are not any more genotypic traits left to select. Maybe we have done all we can with tall fescue at this point.

There are additional things that should be done as we progress through the subsequent stages of this research. After the second year of data collection the 
number of cultivars to be evaluated should be reduced and perennial ryegrass cultivars added along with 'Kentucky 31' tall fescue. The large number of comparisons reduced some of the power of the Tukey's multiple comparisons analysis. Fewer cultivars may give us more significant differences between the cultivars and mowing heights.

As stated, using 'Kentucky 31' in the experiment will give us a better standard of comparison. 'Kentucky 31' was the first cultivar of tall fescue and is often used as a control. Our experiment chose to use 18 of the best performing cultivars from the latest NTEP trials and the differences between them may be minute. Adding 'Kentucky 31' would have assured us that, in-fact, the cultivars were better than the standard and would provide a point of comparison.

The rating of plant quality indicators could also be improved. Possibly using a more quantitative approach rather than qualitative visual ratings may have helped us to obtain more accurate data. Experiments are being conducted to find better ways of rating turfgrass performance.

Experiments at Oklahoma State University found that a vehicle mounted optical sensor can be an accurate measure for rating color and density, but not leaf texture (Bell, 2002). I agree to an extent that using technology may work well to rate turfgrass, but the human eye will always be the best test. I feel, however, that the disadvantage of using technology to rate turfgrass is that equipment can 'see' in much closer detail than the human eye. There can be no difference in quality unless humans can detect a difference with their own eyes. What good does it do if the machine 
finds a difference but we do not? Ultimately, it is what we see that really needs to be tested.

As this experiment will continue for another year, the ultimate goal of this project still remains; to find a cultivar of tall fescue that performs best in the central California coastal region. 


\section{Bibliography}

Alshammary, S.F., Y.L. Qian, and S.J. Wallner. 2004. Growth response for four turfgrass species to salinity. Agricultural Water Management. 66: 97-111.

Bacon, C.W. 1993. Abiotic stress tolerances (moisture, nutrients) and photosynthesis in endophyte-infected tall fescue. Agr. Ecosyst. Environ. 44:123-141.

Beard, J.B. 2002. Turf management for golf courses. Ann Arbor Press: Michigan.

Bell, G. E., D.L. Martin, S.G. Wiese, D.D. Dobson, M.W. Smith, M.L. Stone, J.B. Solie 2002. Vehicle-mounted optical sensing: An objective means for evaluating turf quality. Crop Science. 42: 197-201.

Buckner, C. and Bush, L.P. 1979. Tall Fescue. American Society of Agronomy, USA.

Burpee, L.L. 1995. Interactions among mowing height, nitrogen fertility, and cultivar affect the severity of Rhizoctonia blight on tall fescue. Plant Dis. 79: 721-726.

Craven, K., Schardl, C., and K. Clay. Classification within the grass family. Available from http://forages.oregonstate.edu/is/tfis/enmain.cfm?PageID=342 (accessed November 2007)

Darbyshire, S.J. 1993. Realignment of Festuca Subgenus with the Genus Lolium (Poaceae). Novon. 3(3): 239-243.

Duble, R.L. Tall fescue. Texas Cooperative Extension. http://plantanswers.tamu.edu/turf/publications/tallfesc.html. 
Duncan, R.R., R.N. Carrow, and M. Huck. September/October 2000. Understanding water quality and guidelines to management. USGA Green Section Record. p.14-24.

Endophyte enhanced grasses fact sheet, University of Rhode Island. Available online http://www.uri.edu/ce/factsheets/sheets/endophyte.html (accesses March 2008)

Erickson, J.E., J.L. Cisar, J.C. Volin, and G.H. Snyder. Nov/Dec 2001. Comparing nitrogen runoff and leaching between newly established St. Augustinegrass turf and an alternative residential landscape. Crop Science. 41 (6):p. 18891895.

Ervin, E.H. and A.J. Koski. 1998. Drought avoidance aspects and crop coefficients of Kentucky bluegrass and tall fescue. Crop Science. 38: 788-796.

Flowering Plant Families, University of Hawaii. Available online http://www.botany.hawaii.edu/FACULTY/CARR/po.htm (accessed October 2007).

Grass growth and regrowth for improved management. Oregon State University. Available online http://forages.oregonstate.edu/projects/regrowth/main.cfm?PageID=13 (accessed November 2007)

Grossi, N., M. Volterrani, S. Magni and S. Miele. 2004. Tall fescue turf quality and soccer playing characteristics as affected by mowing height. Acta Hort. (ISHS) 661:319-322 
Hoveland, C.S. Origin and history of tall fescue. University of Georgia. Available online http://forages.oregonstate.edu/is/tfis/book/tf21c/origin-and-history.pdf (accessed October 2007)

Kasperbauer, M.J. 1990. Biotechnology in tall fescue improvement. CRC Press: Florida.

Lacefield, G., and J.K. Evans. 1984. AGR-108 Tall Fescue in Kentucky. Available online http://www.ca.uky.edu/agc/pubs/agr/agr108/agr108.htm. (Accessed 25 October 2008)

National Turfgrass Evaluation Program. Available online http://www.ntep.org/data/tf01/tf01_06-12f/tf01_06-12f.pdf (accessed October 2007).

Neotyphodium and the grass endophytes, University of Sydney. Available online http://bugs.bio.usyd.edu.au/Mycology/Plant_Interactions/Endophytes/grassEn dophytes.shtml (Accessed 15 February 2008)

Qian, Y., J. Fry, and W. Upham. (May/June 1997). Rooting and drought avoidance of warm-season turfgrasses and tall fescue in Kansas. Crop Science. 37(3), p. 905-910.

Ray, W., G. Picchioni, D. VanLeeuwen, and R. Goss. 2007. First year response of turf type tall fescue cultivars to different fertilization rates and mowing heights in semiarid conditions. Hort Technology. 17: 276-401.

Richie, W.E., R.L. Green, G.J. Klein, and J.S. Hartin. 2002. Tall fescue performance influenced by irrigation scheduling, cultivar, and mowing height. Crop Science. 42 (6): 2011-2017. 
Rochefort, S., Y. Desjardins, D. Shetlar, and J. Brodeur. 2007. Establishment and survival of endophyte-infected and uninfected tall fescue and perennial ryegrass overseeded into existing Kentucky bluegrass lawns in northeastern North America. HortScience. 42(3): 682-687.

Snow, J.T. 2001. Water conservation on golf courses. Water Right-conserving Our Water Preserving Our Environment. 7: 48.

Taiz, Lincoln, and Eduardo Zeiger. 2006. Plant Physiology. Sinauer Associates: Massachusetts.

Tredway, L.P. 2005. Managing disease of tall fescue. North Carolina State University Plant Pathology Extension. Available online http://www.ces.ncsu.edu/depts/pp/notes/Turfgrass/Turf006/Turf006.html.

Turgeon, A.J. 2005. Turfgrass management. Pearson Education: New Jersey.

Walker, K.S., C.A. Bigelow, D.R. Smith, G.E. Van Scoyok, and Z.J. Reicher. 2007. Above ground responses of cool season lawn species to nitrogen rates and application timing. Crop Science. 47: 1225-1236.

White, R.H., M.C. Engelke, S.J. Morton, J.M. Johnson-Cicalese, and B.A. Ruemmele. 1992. Acremonium endophyte effects on Tall fescue drought tolerance. Crop Science. 32: 1392-1396. 